\title{
Direkt antikoagulánsok a gyakorlatban. Az ARISTOPHANES-vizsgálat eredményei
}

\author{
Komócsi András \\ Pécsi Tudományegyetem Klinikai Központ, Szívgyógyászati Klinika, Pécs \\ Levelezési cím: \\ Prof. dr. Komócsi András, e-mail: komocsi.andras@pte.hu
}

Az ARISTOPHANES retrospektív, megfigyeléses vizsgálatban számos adatforrás felhasználásával, nagyszámú nonvalvuláris pitvarfibrillációban szenvedő, nem K-vitamin-antagonista típusú orális antikoagulánst vagy warfarint szedő betegnél hasonlították össze a stroke/szisztémás embolizáció és a súlyos vérzés gyakoriságát. A DOAC-okkal és warfarinnal ez idáig végzett legnagyobb obszervációs vizsgálatban a stroke/SE alacsonyabb és a súlyos vérzés változó gyakorisága igazolódott DOAC-ok alkalmazása mellett a warfarinhoz képest, további adatokat szolgáltatva a tromboembóliás és a vérzéses kockázatok közötti egyensúly mérlegeléséhez a terápiás döntéshozatalban.

Kulcsszavak: pitvarfibrilláció, stroke-prevenció, postmarket adatbázis-elemzés

Direct anticoagulants in the daily practice. Results of the ARISTOPHANES study

The ARISTOPHANES retrospective observational study compared stroke / systemic embolization and severe bleeding in a large number of patients treated with direct, non-vitamin $\mathrm{K}$ antagonist oral anticoagulants or warfarin using an extentensive set of data sources. In the largest observational study to date with DOACs and warfarin, lower stroke / SE and variable bleeding rates were confirmed with DOACs compared to warfarin. These provide additional data to balance the risk of thromboembolism and bleeding in therapeutic decision-making.

Keywords: atrial fibrillation, stroke prevention, post-market database analysis

A stroke és a perifériás embolizáció megelőzése a pitvarfibrilláló betegek kezelésében kiemelt prioritású feladat. A stroke-rizikót jelző rizikófaktorok fennállása esetén orális antikoaguláns-kezelés folytatása javasolt, ami az embóliás események és a halálozás kockázatának csökkentését eredményezi. Az első nem K-vitamin-antagonista, direkt orális antikoaguláns (DOAC) piacra kerülése óta több mint tíz év telt el. A DOAC-okkal kapcsolatos klinikai vizsgálatok és az egyre szélesedő gyakorlati tapasztalatok egyértelmüen alátámasztják, hogy ezek a szerek kifejezetten hatásos, megbízható véralvadásgátlást biztosítanak. $A$ véralvadási kaszkád közvetlen gátlásán alapuló gyógyszerek mára már széles körben elfogadottak, a fejlett országokban, több indikációban gyakorlatilag leváltották a K-vitamin-antagonistákat (KVA). Szemben a szük terápiás ablakú
KVA-val a DOAC-ok alkalmazása néhány klinikai paramétert figyelembe vevő, egyszerü dozírozási protokollokkal végezhető, és nem igényli az elért hatás laboratóriumi monitorozását, valamint az ennek alapján történő dóziskorrekciókat. DOAC-ok esetében kevésbé jelentősek a KVA-ra jellemző gyakori gyógyszer- és élelmiszer-kölcsönhatások (1).

A hagyományos alvadásgátló-kezeléssel összevetve több indikációs területen a DOAC-ok hatékonysága hasonló, vagy meghaladja a KVA-val elért hatékonyságot. Ide tartozik a pulmonalis embólia (PE), mélyvénás trombózis (DVT) kezelése és a szisztémás embolizáció és a stroke megelőzése pitvarfibrillációban (PF) szenvedő betegeknél, valamint a DVT megelőzése nagy ortopédiai mütét után.

A pitvarfibrilláló betegek közt végzett nagy létszámú,

A kézirat 2020. 02. 25-én érkezett a szerkesztőségbe, 2020. 03. 19-én került elfogadásra. 
véletlen besorolású klinikai vizsgálatok során a warfarin kontrollcsoportban észlelthez képest mindegyik DOAC-szer és dózis mellett csökkent az iszkémiás események száma (2). A csökkenés mértéke azonban különböző volt az egyes szerek és dózisok használata esetén. A DOAC-ok megváltoztatták a PF-ben az antikoaguláció használatát, de hasonlóságaik mellett számos különbség is jellemzi ezeket a gyógyszereket. Ezek közé a különbségek közé tartoznak olyan farmakológiai eltérések, amelyek érintik a hatásmechanizmust, a felszívódás táplálkozástól való függését és a vesén keresztül történő kiválasztás mértékét (3).

A biztonságosság tekintetében a forgalombahozatal előtti, III. fázisú vizsgálatok eredményei még vegyesebb eredményeket mutattak. Általánosságban elmondható, hogy a DOAC-gyógyszerek mellett ritkábban jelentkezett életveszélyes és intracranialis vérzés. Bizonyos esetekben azonban a gasztrointesztinális vérzések száma magasabb volt (2).

A DOAC-szerek piacra kerülését megalapozó klinikai vizsgálatok számos kérdésre nem adtak megfelelő választ. Fontos hangsúlyozni, hogy a randomizált vizsgálatok hasonló összeállítási szerkezet követésével kerültek kivitelezésre, de a bevont betegcsoport különbözőségei és a vizsgálatok közti módszertani különbségek miatt a DOAC-ok közti összehasonlítást nem teszik lehetővé (4). Eddig ezeknek a hatóanyagoknak közvetlen, véletlen besorolású vizsgálatból származó összehasonlítása nem áll rendelkezésre. A vizsgálat költségei és megvalósítási nehézségei miatt nem is várható, hogy ilyen összetételü randomizált vizsgálat belátható időn belül segíteni fogja a gyógyszerválasztást. A gyógyszerek hatékonyságának és biztonságosságának forgalomba kerülés utáni követését ezzel szemben több obszervációs vizsgálat is célul tűzte ki. Ezek általában egyetlen adatforrás felhasználásával értékelték a DOAC-ok használata melletti adverz események gyakoriságát. Az obszervációs vizsgálatok további bizonyítékokat nyújtottak az DOAC-ok hatékonyságára, és kiegészítve a randomizált vizsgálatok adatait, lehetővé tették - még ha korlátos formában is - a gyógyszerek megegyező körülmények közötti összehasonlító elemzését. Az alkalmazott módszertanból adódó korlátok és az alcsoportok közötti teljes körü értékelés hiánya azonban csökkenti az ezekben a vizsgálatokban észleltek általánosíthatóságát.

\section{ARISTOPHANES-vizsgálat}

Az ARISTOPHANES-vizsgálat nagyszámú pitvarfibrillációs beteg között, több adatforrást felhasználva célozta meg a stroke/szisztémás embólia (SE) és a súlyos vérzés (major vérzés, MV) összehasonlítását a nem K-vitamin-antagonista orális antikoagulánsok vagy warfarin használata esetén (5).

A vizsgálat összeállítása retrospektív, obszervációs jel- legű volt. Az adatgyűjtés során azon betegek adatait szűrték le, akik a nem valvularis pitvarfibrilláció miatt szorultak antikoagulálásra, és az USA Medicare és Medicaid központjai, valamint 4 amerikai kereskedelmi gyógyszerelési adatbázis alapján 2013. január 1-jétől 2015. szeptember 30-áig apixaban-, dabigatran-, rivaroxaban- vagy warfarinkezelést kezdtek. A vizsgált adatbázisok évente több mint 180 millió kedvezményezett egészségügyi ellátását fedik le, ami az Egyesült Államok népességének $56 \%$-át jelenti.

Az egyes gyógyszerekkel való kezelés valószínűségét elemezték, majd a klinikai jellemzőkből adódó különbségeket az egyes adatbázisokban valószínűségi pontszám (propensity score, PS) alapú párosítással egyensúlyozták ki. A PS kiszámításához a betegek demográfiai adatai, a Charlson Komorbiditási Index pontszám, a kiindulási vérzés és a stroke/SE-előzmények, a társbetegségek és a betegek által szedett egyéb gyógyszerek is felhasználásra kerültek. A párosításokat adatbázisonként külön végezték el, majd az így kapott kohorszokat összevonták. Az így kialakított kezelési csoportok között Cox-modellek felhasználásával végezték el a stroke/SE és az MV kockázatának kiértékelését.

A vizsgálat adatait feldolgozó közleményben először 321182 beteg adatait ismertették. A cikk megjelenését követően észlelték, hogy abban az eredeti adatforrások közt szerepelő CMS Medicare adatai nem kerültek be. Ezért az eredeti közlemény adatait korrigálták, és így 466991 antikoagulált beteg adatai állnak rendelkezésre. A kéziratot közlő Stroke honlapján is a korrigált adatokat tartalmazó közlemény érthető el, így jelen öszszefoglalóban is ennek az adatait ismertetjük.

\section{Eredmények}

A 466991 betegből a gyógyszerelés alapján kialakított 6 párosított csoportban elemezték a klinikai események és a mortalitás alakulását. 100977 apixaban-warfarin, 36990 dabigatran-warfarin, 125068 rivaroxaban-warfarin, 37314 apixaban-dabigatran, 107236 apixaban-rivaroxaban és 37693 dabigatran-rivaroxaban betegpár adatai kerültek kiértékelésre.

A warfarinhoz képest mindhárom DOAC-szer alkalmazása jelentősen csökkentette a stroke/SE előfordulását. A kockázati arány [HR] apixaban esetében 0,64 ; 95\% Cl: 0,58-0,70 (1. ábra), a dabigatran mellett HR: 0,$82 ; 95 \% \mathrm{Cl}: 0,71-0,95$ (2. ábra) és a rivaroxaban esetén HR: 0,79; 95\% Cl: 0,73-0,85 (3. ábra) volt.

$A z$ összes DOAC-ok esetében alacsonyabb volt a vérzéses stroke gyakorisága, míg az apixabannal és a rivaroxaban kezeltek közt alacsonyabb iszkémiás stroke előfordulást mutattak ki, mint a warfarinnal kezeltek közt. A súlyos vérzések kockázata warfarinhoz képest az apixabannal (HR: 0,60; 95\% Cl: 0,56-0,63) (1. ábra) és a dabigatrannal kezeltek közt (HR: 0,71; 95\% Cl: 


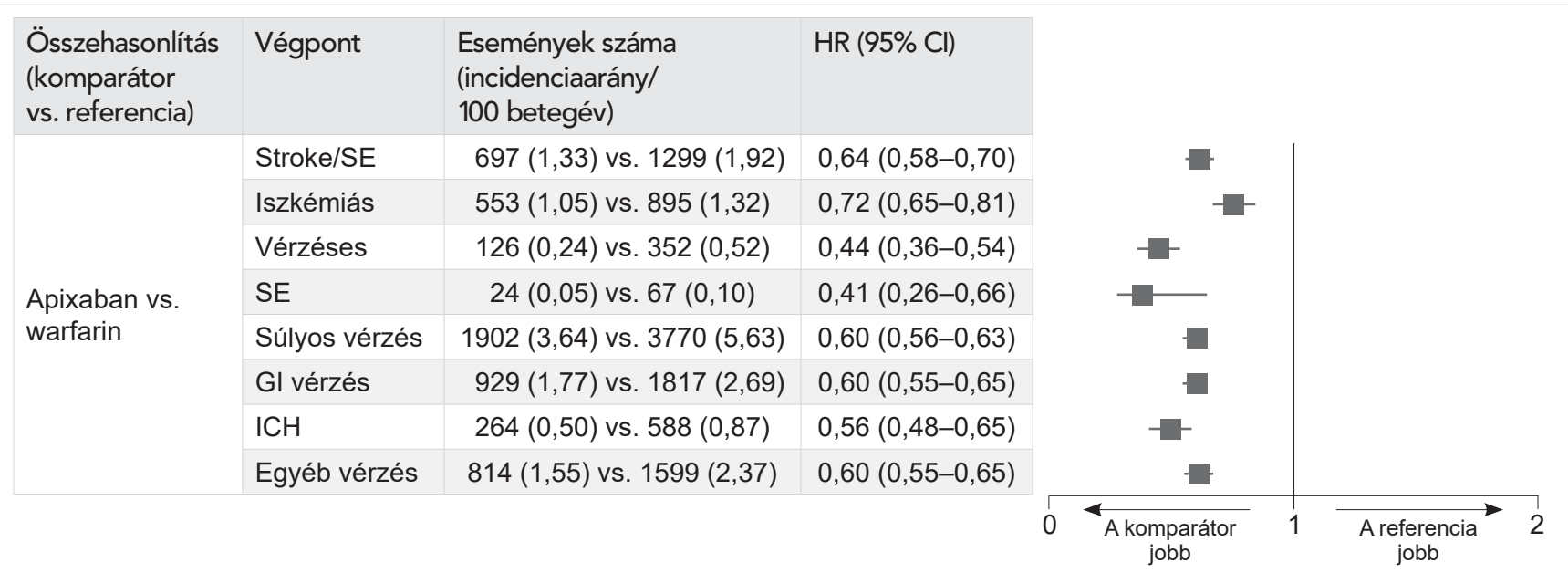

1. ÁBRA. Hatékonyság és biztonságosság: stroke/SE és súlyos vérzés gyakorisága NVPF-betegeknél apixaban-warfarin összehasonlítás tekintetében

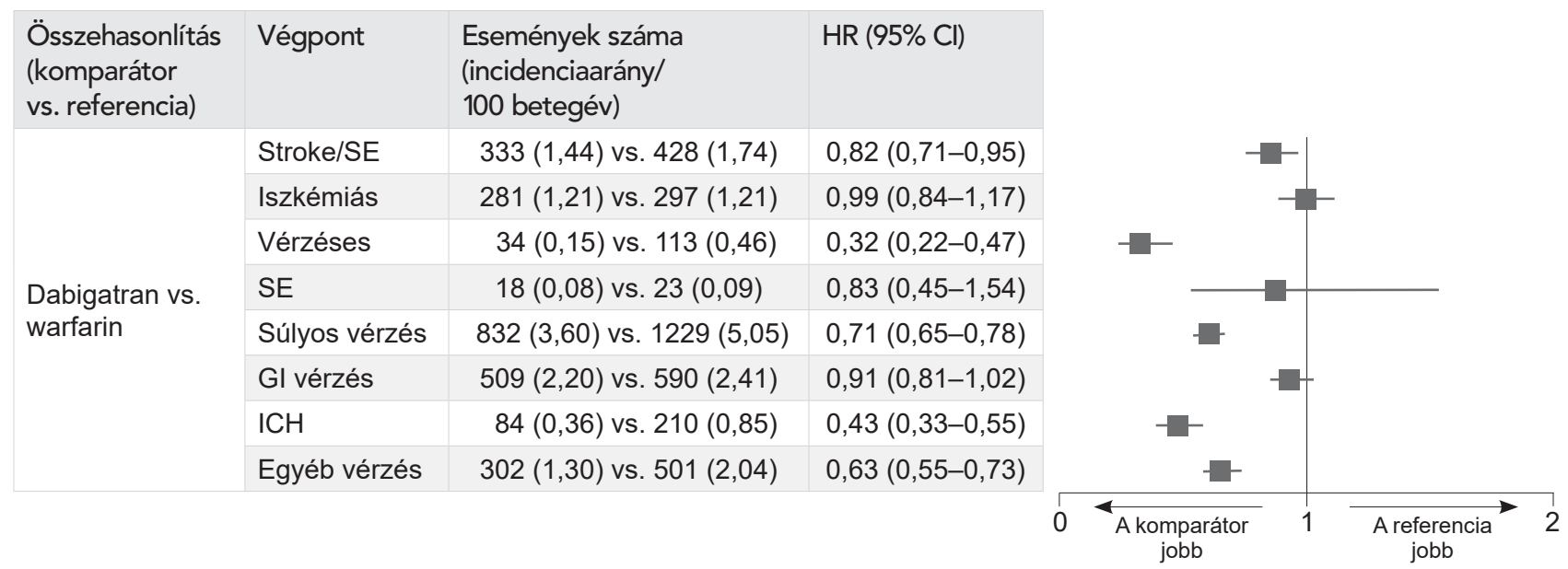

2. ÁBRA. Hatékonyság és biztonságosság: stroke/SE és súlyos vérzés gyakorisága NVPF-betegeknél dabigatran-warfarin összehasonlítás tekintetében

\begin{tabular}{|l|l|c|l|}
\hline $\begin{array}{l}\text { Összehasonlítás } \\
\text { (komparátor } \\
\text { vs. referencia) }\end{array}$ & Végpont & $\begin{array}{l}\text { Események száma } \\
\text { (incidenciaarány/ } \\
100 \text { betegév) }\end{array}$ & HR $(95 \%$ Cl) \\
\hline & Stroke/SE & $1203(1,51)$ vs. $1593(1,90)$ & $0,79(0,73-0,85)$ \\
\hline & Iszkémiás & $889(1,11)$ vs. $1096(1,30)$ & $0,85(0,77-0,92)$ \\
\cline { 2 - 4 } & Vérzéses & $244(0,31)$ vs. $437(0,52)$ & $0,59(0,50-0,69)$ \\
\hline \multirow{2}{*}{$\begin{array}{l}\text { Rivaroxaban vs. } \\
\text { warfarin }\end{array}$} & SE & $77(0,10)$ vs. $(80(0,09)$ & $1,00(0,73-0,37)$ \\
\hline & Súlyos vérzés & $4607(5,83)$ vs. $4541(5,45)$ & $1,06(1,02-1,10$ \\
\hline & Gl vérzés & $2608(3,28)$ vs. $2198(2,62)$ & $1,24(1,17-1,31)$ \\
\hline & ICH & $452(0,57)$ vs. $750(0,89)$ & $0,63(0,56-0,71)$ \\
\hline & Egyéb vérzés & $1922(241)$ vs. $1854(2,21)$ & $1,08(1,02-1,15)$ \\
\hline
\end{tabular}

3. ÁBRA. Hatékonyság és biztonságosság: stroke/SE és súlyos vérzés gyakorisága NVPF-betegeknél rivaroxaban-warfarin összehasonlítás tekintetében 
0,65-0,58) (2. ábra) alacsonyabb volt. A rivaroxaban esetében a warfarinhoz képest magasabb volt az MV gyakorisága (HR: 1,06; 95\% Cl: 1,02-1,10) (3. ábra). Mindhárom DOAC alkalmazása alacsonyabb intracranialis vérzés kockázattal járt a warfarinhoz viszonyítva. A gasztrointesztinális vérzés aránya alacsonyabb volt apixaban (HR: 0,60; 95\% Cl: 0,55-0,65) (1. ábra), és magasabb rivaroxaban alkalmazása esetén (HR: 1,24; 95\% Cl: 1,17-1,31) (3. ábra) a warfarinhoz képest.

Mind a stroke/SE és az MV-arány alacsonyabb volt az apixabannal kezeltek közt a dabigatranhoz (stroke/SE: HR: 0,72; 95\% Cl: 0,60-0,85; MV: HR 0,78; 95\% Cl: $0,70-0,87$ ) (4. ábra) és rivaroxabanhoz képest (stroke/ SE: HR 0,80; 95\%; Cl: 0,73-0,89; MV: HR, 0,55; 95\% Cl: 0,53-0,59) (5. ábra). A dabigatran alacsonyabb vérzésarányt $(\mathrm{HR}, 0,71 ; 95 \% \mathrm{Cl}$ : 0,65-0,78) mutatott a rivaroxabanhoz képest, hasonló mértékű stroke/SEarány mellett (HR: 1,10; 95\% Cl: 0,95-1,23) (6. ábra).
A vizsgálat alcsoportelemzései a korosztályra, a nemre és a $\mathrm{CHA}_{2} \mathrm{DS}_{2}$-VASc-pontszámra, a HAS-BLED-pontszámra, a pangásos szívelégtelenségre, a koszorúér-betegségre, a perifériás artériás betegségre, a cukorbetegségre, a vesebetegségre és a korábbi stroke/ SE-re vonatkozó eredmények tekintetében általában konzisztensek voltak a főbb eredményekkel. Kiemelendő, hogy a stroke/SE kockázatcsökkenés nagysága az apixabannal, szemben a warfarinnal, nagyobb volt a nőbetegek közt, valamint azoknál, akiknél a kiinduló $\mathrm{CHA}_{2} \mathrm{DS}_{2}$-VASc-pontszám magas volt.

A súlyos vérzések esetében szingnifikáns interakciót észleltek a DOAC-warfarin összevetésekben a kor a nem és a stroke-rizikót felmérő $\mathrm{CHA}_{2} \mathrm{DS}_{2}$-VASc-pontszámmal. Ezekben az összevetésekben alacsonyabb rizikóarány volt kimutatható a fiatalabb, a férfi és az alacsony $\mathrm{CHA}_{2} \mathrm{DS}_{2}$-VASc-pontszámú betegek közt.

A vizsgálatba a Medicare keretében ellátást kapó be-

\begin{tabular}{|l|l|c|l|}
\hline $\begin{array}{l}\text { Összehasonlítás } \\
\text { (komparátor } \\
\text { vs. referencia) }\end{array}$ & Végpont & $\begin{array}{l}\text { Események száma } \\
\text { (incidenciaarány/ } \\
\text { 100 betegév) }\end{array}$ & HR $(95 \% \mathrm{Cl})$ \\
\hline & Stroke/SE & $215(1,12)$ vs. $333(1,43)$ & $0,72(0,60-0,85)$ \\
\hline & Iszkémiás & $175(0,91)$ vs. $280(1,20)$ & $0,69(0,57-0,84)$ \\
\cline { 2 - 4 } & Vérzéses & $34(0,18)$ vs. $35(0,15)$ & $1,09(0,69-1,74)$ \\
\hline $\begin{array}{l}\text { Apixaban vs. } \\
\text { dabigatran }\end{array}$ & SE & $7(0,04)$ vs. $18(0,08)$ & $0,44(0,18-1,06)$ \\
\hline & Súlyos vérzés & $571(2,98)$ vs. $832(3,58)$ & $0,78(0,70-0,87)$ \\
\hline & Gl vérzés & $294(1,53)$ vs. $508(2,18)$ & $0,66(0,57-0,76)$ \\
\hline & ICH & $77(0,40)$ vs. $85(0,36)$ & $1,04(0,76-1,42)$ \\
\hline & Egyéb vérzés & $235(1,22)$ vs. $302(1,29)$ & $0,88(0,74-1,04)$ \\
\hline
\end{tabular}

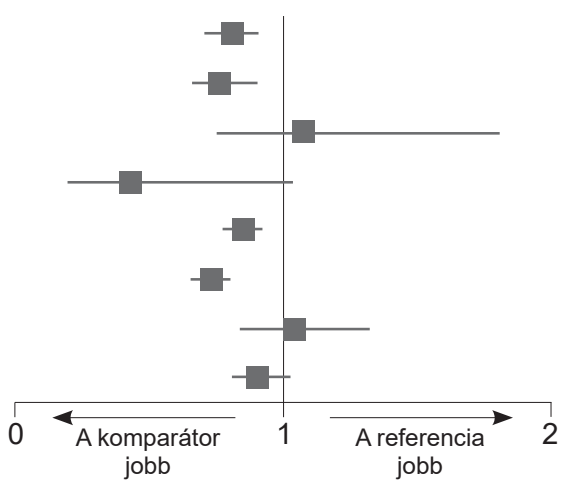

4. ÁBRA. Hatékonyság és biztonságosság: stroke/SE és súlyos vérzés gyakorisága NVPF-betegeknél apixaban-dabigatran összehasonlítás tekintetében

\begin{tabular}{|c|c|c|c|}
\hline $\begin{array}{l}\text { Összehasonlítás } \\
\text { (komparátor } \\
\text { vs. referencia) }\end{array}$ & Végpont & $\begin{array}{l}\text { Események száma } \\
\text { (incidenciaarány/ } \\
100 \text { betegév) }\end{array}$ & $\mathrm{HR}(95 \% \mathrm{Cl})$ \\
\hline \multirow{8}{*}{$\begin{array}{l}\text { Apixaban vs. } \\
\text { rivaroxaban }\end{array}$} & Stroke/SE & $710(1,28)$ vs. $1008(1,47)$ & $0,80(0,73-0,89)$ \\
\hline & Iszkémiás & $559(1,01)$ vs. $749(1,10)$ & $0,85(0,76-0,95)$ \\
\hline & Vérzéses & $130(0,23)$ vs. $206(0,30)$ & $0,73(0,59-0,91)$ \\
\hline & SE & $26(0,05)$ vs. $62(0,09)$ & $0,47(0,29-0,74)$ \\
\hline & Súlyos vérzés & $1948(3,52)$ vs. $3981(5,88)$ & $0,55(0,53-0,59)$ \\
\hline & GI vérzés & $952(1,71)$ vs. $2239(3,29)$ & $0,48(0,44-0,52)$ \\
\hline & $\mathrm{ICH}$ & $272(0,49)$ vs. $375(0,55)$ & $0,86(0,73-1,00)$ \\
\hline & Egyéb vérzés & $836(1,50)$ vs. $1680(2,46)$ & $0,57(0,52-0,61)$ \\
\hline
\end{tabular}

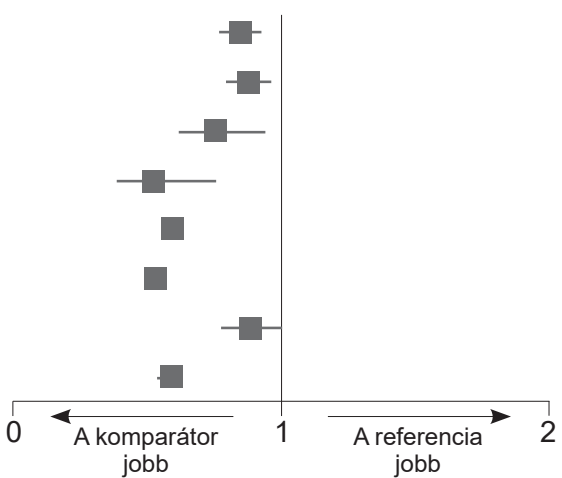

5. ÁBRA. Hatékonyság és biztonságosság: stroke/SE és súlyos vérzés gyakorisága NVPF-betegeknél apixaban-rivaroxaban összehasonlítás tekintetében 


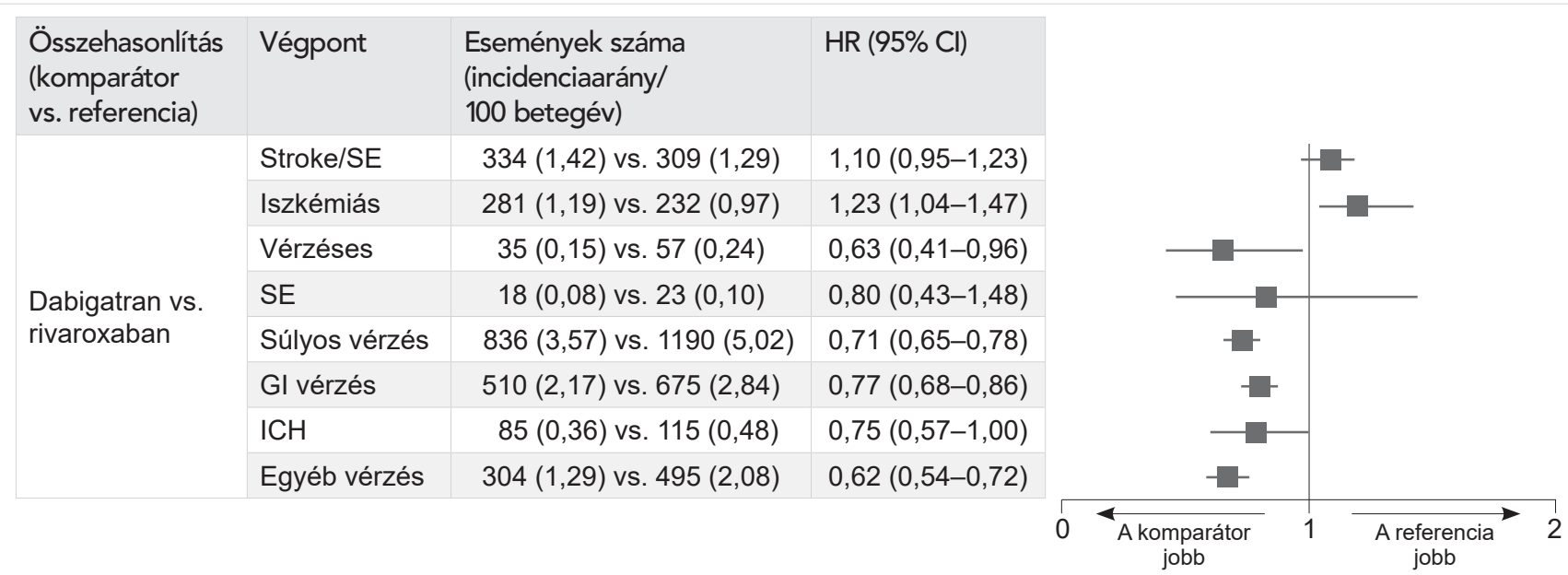

6. ÁBRA. Hatékonyság és biztonságosság: stroke/SE és súlyos vérzés gyakorisága NVPF-betegeknél dabigatran-rivaroxaban összehasonlítás tekintetében

tegek közt - alcsoportelemzés formájában - lehetőség nyílt a mortalitási adatok elemzésére is. Ennek során alacsonyabb halálozási mutatókat észleltek az összes DOAC esetében a warfarinnal összehasonlítva. Az apixabannal kezeltek halálozási aránya alacsonyabb volt, mint a dabigatrannal és a rivaroxabannal kezelteké.

\section{Megbeszélés}

Összefoglalva, az ARISTOPHANES az eddigi legnagyobb retrospektív megfigyeléses vizsgálat, amely a stroke/SE és az MV kockázatát vizsgálta a DOAC-kezelést kezdő PF-betegek körében. A tanulmány megerősítette, hogy az apixaban, a dabigatran és a rivaroxaban csökkenti a stroke/SE-arányt a warfarinnal összehasonlítva. Emellett rámutatott, hogy a DOAC-okkal kapcsolatos biztonságossági eredmények jelentős különbségeket mutatnak.

Az ARISTOPHANES-vizsgálat eredményei fontos kiegészítő adatokat nyújtanak a klinikai vizsgálatok eredményeinek értelmezéséhez. A gyógyszerek forgalombahozatalát megelőző randomizált klinikai vizsgálatok mindegyik DOAC esetében bizonyították, hogy az általuk biztosított antikoaguláns hatás stroke-prevenció és major vérzések tekintetében nem alacsonyabb értékü, mint a warfariné. Az apixaban és a warfarin összehasonlításának eredményei hasonlóak voltak az ARISTOTLE-vizsgálat eredményeihez, ahol az apixaban hatékonyabb volt a warfarinnál a stroke/SE megelőzésében és az MV kockázatának csökkentésében. A RE-LY-vizsgálatban a 150 mg dabigatran alacsonyabb stroke/SE-kockázattal és hasonló MV-kockázattal társult; az ARISTOPHANES-tanulmányban azt tapasztalták, hogy a dabigatran esetében jelentősen csökkent mind a stroke/SE, mind az MV kockázata. A ROCKET-AF-vizsgálatban rivaroxaban mellett mind a stroke/SE, mind az MV esetében noninferioritás iga- zolódott; az ARISTOPHANES szignifikánsan alacsonyabb stroke/SE-kockázatot, viszont statisztikailag szignifikánsan emelkedett vérzési kockázatot mutatott.

Az ARISTOPHANES-vizsgálat nyilvánvaló erősségei mellett, amelyek a korábbi forgalomba hozatalt követő obszervációs vizsgálatokkal történő összevetésben a jelentős létszámból és a vizsgálati metodika alaposságából adódnak, meg kell említenünk, hogy az mint retrospektív obszervációs tanulmány számos korláttal is rendelkezik. Először is, a tanulmány egészségügyi finanszírozási adatok visszamenőleges analízisén alapul. Mivel ezen adatok gyújtésének célja és módszere nem vethető össze a klinikai vizsgálatok hasonló adataival, ezért ilyen értelemben az analízis eredményeit sem értékelhetjük a klinikai vizsgálatokkal egy szinten. Statisztikai értelemben a kiértékelések csak bizonyos faktorok kapcsolódását, asszociációját alkalmasak kimutatni, és nem alkalmasak okozati összefüggések meghatározására. A kohorszokat kezelési valószínűségen alapuló párosítással illesztették, ami a vizsgált paraméterek megfelelő kiegyensúlyozásához vezetett, azonban ez a módszer nem váltja ki a valódi, véletlenszerü besorolást, a randomizációt. A PS-illesztés során nem tudjuk kizárni olyan fennmaradó, zavaró tényezők létezését, amelyek nem kerülnek kiegyensúlyozásra, de az eredményeket befolyásolhatták. A klinikai gyakorlatban a különböző DOAC-okat kapó betegek szisztematikusan eltérőek lehetnek, és amennyiben ezek a különbségek nem kerülnek észlelésre, ez a vizsgálati eredmények torzulásához vezethet. Ez a korlátozó szempont különösen fontos azokban az összehasonlításokban, amelyek során az egyes DOAC-okat egymással vetik össze. Figyelembe véve ezeket a szempontokat, az obszervációs, és különösen a retrospektív adatfeldolgozáson alapuló obszervációs vizsgálatok során észlelt eltérések elsősorban feltételezések generálására tekinthetők alkalmasnak. 


\section{Következtetések}

A tanulmány eredményei segíthetik az elönyök és a kockázatokkal kapcsolatos párbeszédet az egészségügyi szolgáltatók, az egészségügyi személyzet és a pitvarfibrilláló betegek között. Ebben a stroke-megelőzéssel kapcsolatos közös döntéshozatali folyamatban az ARISTOPHANES-vizsgálat további adatokkal szolgál a tromboembóliás és a vérzési kockázatok közötti egyensúly mérlegeléséhez.

\section{Nyilatkozat}

A cikk megjelenését a Pfizer Gyógyszerkereskedelmi Kft. támogatta. A referenciadokumentumok a szerzőnél megtalálhatók.

Lezárás dátuma: 2020. 02. 18.

PP-ELI-HUN-0175
Irodalom

1. Komócsi A. Antitrombotikus és antikoaguláns-kezelés szívbetegségekben. Magy Belorv Arch 2018; 71(5): 229-39.

2. Ruff CT, Giugliano RP, Braunwald E, Hoffman EB, Deenadayalu $\mathrm{N}$, Ezekowitz MD, et al. Comparison of the efficacy and safety of new oral anticoagulants with warfarin in patients with atrial fibrillation: a meta-analysis of randomised trials. Lancet (London, England) 2014 Mar 15; 383(9921): 955-62. doi: 10.1016/S0140-6736(13)62343-0 3. Steffel J, Verhamme P, Potpara TS, Albaladejo P, Antz M, Desteghe L, et al. The 2018 European Heart Rhythm Association Practical Guide on the use of non-Vitamin K antagonist oral anticoagulants in patients with atrial fibrillation: Executive summary. Europace 2018 doi: 10.1093/eurheartj/ehy136.

4. Camm AJ, Fox KAA, Peterson E. Challenges in comparing the non-vitamin $\mathrm{K}$ antagonist oral anticoagulants for atrial fibrillation-related stroke prevention. Europace 2018 Jan 1; 20(1): 1-11. doi: 10.1093/europace/eux086.

5. Lip GYH, Keshishian A, Li X, Hamilton M, Masseria C, Gupta $\mathrm{K}$, et al. Effectiveness and Safety of Oral Anticoagulants Among Nonvalvular Atrial Fibrillation Patients. Stroke 2018 Dec; 49(12) 2933-44. doi: 10.1161/STROKEAHA.118.020232.0 